\title{
Historical changes in El Niño and La Niña characteristics in an ocean reanalysis
}

\author{
Sulagna Ray ${ }^{1,2}$ and Benjamin S. Giese ${ }^{1}$ \\ Received 14 March 2012; revised 17 September 2012; accepted 19 September 2012; published 8 November 2012.
}

[1] The variation of El Niño Southern Oscillation (ENSO) events from the mid-nineteenth century until the beginning of the twenty-first century is explored using an ocean reanalysis. A comparison of the reanalysis with three sea surface temperature reconstructions shows that the timing of events is similar in all four products, however there are important differences in the strength and location of events. The difference between the reconstructions is sometimes larger than the difference between the reanalysis and a given reconstruction. These differences are larger in the first half of the record, a period for which there are relatively sparse observations. The reanalysis is used to explore decadal variability and trends in the frequency, duration, and propagation direction of ENSO events. There is considerable decadal variability of these ENSO characteristics with the time between events ranging from several months to ten years and the duration of ENSO varying from 5 to 27 months. As has been previously shown for the strength and location of ENSO there is little overall trend in the characteristics. Having a three dimensional representation of the ocean from the reanalysis allows exploration of subsurface changes during ENSO. An analysis of subsurface anomalies shows that during ENSO events the subsurface anomalies are highly correlated with the strength of surface anomalies over the 140 year period. Overall, there is no evidence that there are changes in the strength, frequency, duration, location or direction of propagation of El Niño and La Niña anomalies caused by global warming during the period from 1871 to 2008 .

Citation: Ray, S., and B. S. Giese (2012), Historical changes in El Niño and La Niña characteristics in an ocean reanalysis, J. Geophys. Res., 117, C11007, doi:10.1029/2012JC008031.

\section{Introduction}

[2] This paper addresses the issue of whether ENSO has changed over the period from 1871 to 2008 . It is widely agreed that the earth's average temperature has warmed over this period of time. What is far less clear is how this warming trend has altered forms of climate variability such as ENSO. The consequences of an altered ENSO could be considerable. For example, Schubert et al. [2004] show that a cool tropical Pacific Ocean and a warm Atlantic Ocean accompanied and aided the dry conditions in North America during the Dust Bowl years. Since El Niño in the Pacific is associated with excess wintertime rainfall in southwest U.S., having reduced El Niño during these years may be responsible for the dry conditions in North America at the time. To provide a context for assessing future climate change it is important to understand the range of variability of climate phenomena such as ENSO.

\footnotetext{
${ }^{1}$ Department of Oceanography, Texas A\&M University, College Station, Texas, USA.

${ }^{2}$ LOCEAN/IPSL, UPMC, Paris, France.

Corresponding author: S. Ray, LOCEAN/IPSL, UPMC, Case 100, 4 Place Jussieu, FR-75252, Paris CEDEX, France. (sulagna.ray@locean-ipsl.upmc.fr)

(C)2012. American Geophysical Union. All Rights Reserved. 0148-0227/12/2012JC008031
}

[3] Evidence from coral records and other proxy data suggest that the nature of ENSO has varied considerably in the past. Recent studies suggest a prominent modulation in El Niño strength and frequency [Cole et al., 1993; Tudhope et al., 2001; Cobb et al., 2003; D'Arrigo et al., 2005; $\mathrm{Li}$ et al., 2011] over centennial to millennial timescales. There is also research that suggests ENSO will change in the future due to warming of earth's climate [Philip and van Oldenborgh, 2006; Merryfield, 2006; Zhang et al., 2008; An et al., 2008; Yang and Zhang, 2008; Ye and Hseih, 2008]. The studies of changing ENSO using the paleoclimate records suffer from high uncertainty and sparse coverage, and studies of changing ENSO in the future are limited by uncertainty in the models used. In this paper we concentrate on a period of time for which there is relatively good spatial and temporal observational coverage, using a methodology that reduces some of the model uncertainty.

[4] There are numerous published articles that document trends and decadal variations in El Niño including changes in frequency [Timmermann et al., 1999; Trenberth and Hoar, 1996; An and Wang, 2000], strength [Zhang et al., 2008; Vecchi and Wittenberg, 2010] and location of the warming in the equatorial Pacific [Yeh et al., 2009]. Changing external forcing, such as increased concentration of $\mathrm{CO}_{2}$ and volcanic eruptions might also alter ENSO, although there are studies that have shown little response to changes in external 
forcings [van Oldenborgh et al., 2005; Coelho and Goddard 2009]. Trenberth and Hoar [1996, 1997] argue that there has been an increase in the occurrence of El Niños since 1976 and suggest that the change is due to global warming. Lee and McPhaden [2010] show an increase in intensity and occurrence of El Niño events in the central equatorial Pacific since the 1990s, which they suggest increased the temperature of the warm pool region in the western Pacific. A change in the propagation characteristics of anomalous warming during $\mathrm{El}$ Niño from an eastward propagating direction before the 1970 s to a westward propagating direction after the 1970s has been highlighted by several studies [Fedorov and Philander, 2000; Wang and An, 2002; Trenberth et al., 2002]. In recent years studies indicate changes in the onset of El Niño [Wang 1995] during the late 1970s. An and Wang [2000] and Fedorov and Philander [2000] show that weakening of easterlies to the west of the dateline and a change in the periodicity of El Niño from 3 to 5 years occurred in coincidence with a deepening of the thermocline from the 1960s to the 1990s.

[5] Most of these studies use records that are relatively short, on the order of 50 years or less. However, as pointed out by DelSole and Tippett [2009], records shorter that 5060 years are not sufficient to detect trends in a mode of variability such as ENSO. To address the need for long-term SST records several reconstructed SST data sets have been developed. Spatially and temporally complete global data sets such as HadISST1 [Rayner et al., 2003], Kaplan SST v2 [Kaplan et al., 1998], and ERSST [Smith and Reynolds, 2005; Smith et al., 2008] are generated by using statistical interpolation techniques to "reconstruct" the SST field. One drawback of these reconstructions is that they use patterns of climate variability in times of dense observations (mostly the latter part of the twentieth century) to generate patterns of variability for periods of sparse observations. An alternative, the method used here, is to use an ocean reanalysis. In this paper we first compare SST from the ocean reanalysis with three widely used SST reconstructions. We then use the reanalysis to look at change of ENSO characteristics for the period 1871-2008. We finish by looking at the subsurface ocean response during ENSO, something that cannot be done with SST reconstructions.

\section{Methods}

[6] To explore changes in El Niño and La Niña an ocean reanalysis incorporating the Simple Ocean Data Assimilation (SODA) methodology [Carton and Giese, 2008] in an ocean general circulation model is used. This model was used for earlier versions of the SODA ocean reanalysis [Carton et al., 2000a, 2000b; Carton and Giese, 2008; Giese and Ray, 2011]. The ocean general circulation model is based on the Parallel Ocean Model (POP) [Smith et al., 1992] version 2.0.2 and has an average horizontal resolution of $0.25^{\circ} \times 0.4^{\circ}$ with 40 vertical levels with $10-\mathrm{m}$ spacing in the upper $100 \mathrm{~m}$. The domain of the model is global, and the grid is distorted in northern latitudes to allow for a displaced North Pole in order to resolve the Arctic Ocean. The meridional resolution increases poleward of the tropics and reduces the grid anisotropy that comes about in Mercator coordinate grids due to convergence of meridians at high latitudes. The K-profile parameterization (KPP) scheme is used in the vertical mixing scheme and lateral subgrid-scale processes are modeled using a biharmonic-mixing scheme. Rivers are included with climatological seasonal discharge. There is no explicit sea ice model but surface heat flux is modified when the sea surface temperature reaches the freezing point of seawater.

[7] The details of the SODA assimilation system are described by Carton et al. [2000a] and Carton and Giese [2008]. In brief, the assimilation is carried out in a 10-day cycle with corrections introduced incrementally at every time step. The model output variables (temperature, salinity, velocity) are averaged and stored at 5-day intervals. The output is remapped onto a uniform global $0.5^{\circ} \times 0.5^{\circ}$ horizontal grid $(720 \times 330 \times 40$ points $)$ using the horizontal grid spherical coordinate remapping and an interpolation package with second-order conservative remapping [Jones 1999]. Monthly averages are computed and used for this analysis. Although observation density varies considerably over the period of study, Carton et al. [2012] show that in the tropical Pacific Ocean the assimilation makes an important contribution to resolving ENSO even during periods of sparse ocean observations such as during the early part of the twentieth century.

[8] The surface boundary conditions are obtained from the latest available atmospheric reanalysis of the TwentiethCentury Reanalysis Project (20CRv2) [Compo et al., 2011]. 20CRv2 is a first attempt to compute a reanalysis of the global troposphere that extends back to the nineteenth century. The surface wind stress from the atmospheric reanalysis is used for the surface momentum flux in the ocean reanalysis. Solar radiation, $2 \mathrm{~m}$ air temperature, specific humidity, cloud cover, $10 \mathrm{~m}$ wind speed, and precipitation are used in the bulk formulas to calculate the heat and fresh water fluxes used by SODA 2.2.4. A second "simulation" run (SODA 2.2.0) of the model with similar boundary conditions as SODA 2.2.4 but without data assimilation is also performed.

[9] The data assimilation package uses both surface and subsurface observations. Surface temperature data comes from the ICOADS 2.5 data set. Subsurface temperature and salinity observations are obtained from the World Ocean Database 2009 (WOD09) [Boyer et al., 2009]. WOD09 includes all available hydrographic observations collected from buoys, and ships using expendable bathythermograph (XBT) and mechanical bathythermograph (MBT).

[10] Other data sets used include HadISST1 developed at the Met Office Hadley Center for Climate Prediction and Research (HadISST) [Rayner et al., 2003], the Kaplan extended sea surface temperature version 2 (Kaplan) [Kaplan et al., 1998], and the Extended Reconstructed Sea Surface Temperature version 3 (ERSST) developed by the National Oceanic and Atmospheric Administration (NOAA) [Smith and Reynolds, 2005; Smith et al., 2008]. HadISST is a complete field of globally gridded $\left(1^{\circ} \times 1^{\circ}\right)$ monthly SST and sea-ice concentration data from 1871 to the present. A twostage reduced space optimal interpolation (RSOI) procedure is used to reconstruct the SST field with EOFs used to define the spatial structure of SST variability. The RSOI reconstruction is performed in two stages: the long-term climate variability is constructed first followed by the interannual variability. Kaplan SST is a global analysis of monthly SST produced using three statistic-based methods: optimal smoothing, a Kalman filter and optimal interpolation. Kaplan SST also uses the RSOI but the reconstruction is performed in only 

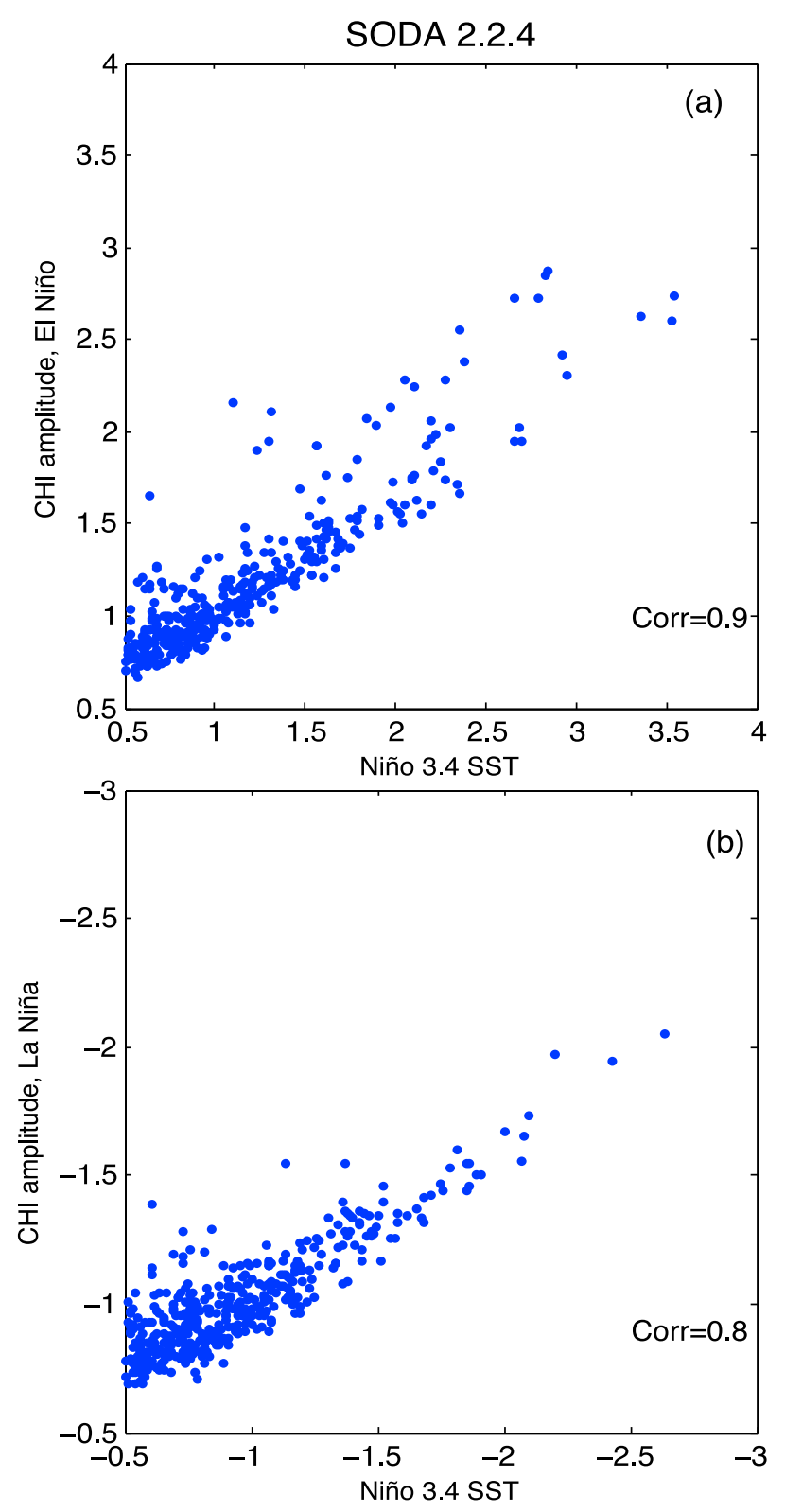

Figure 1. (a) El Niño CHI amplitude plotted as a function of Niño 3.4 SST anomaly. (b) As in Figure 1a, but for La Niña. The respective correlation coefficients are shown in the figures.

one stage. ERSST is a monthly and globally complete gridded SST data set generated with statistical methods that allow stable reconstruction using sparse data. ERSST reconstructs the low frequency component and the high frequency component separately before merging them as the total reconstruction.

[11] To define SST anomalies we remove an 11-year running climatology. This approach is similar to that used by Fedorov and Philander [2001]. This technique results in a climatology that is long enough to be largely unaffected by a strong El Niño or La Niña event but is short enough to remove decade-to-decade variability and trends that make the interannual signal difficult to analyze. The first five years (1871-1875) and the last five years (2004-2008) have a fixed climatology based on the first and last 11-year periods. Giese and Ray [2011] show that there are some small changes in the amplitude of interannual anomalies as a result of using an 11-year climatology compared to anomalies calculated by removing a constant climatology, but the timing and duration of events remains the same.

[12] In this paper we use an ENSO metric called the Center of Heat Index (CHI) as proposed by Giese and Ray [2011] to measure the amplitude and location of interannual temperature anomalies. CHI is the first moment of SST anomaly and has two components, $\mathrm{CHI}$ amplitude and $\mathrm{CHI}$ longitude. $\mathrm{CHI}$ amplitude is the average temperature anomaly calculated over a region for which the temperature anomaly is greater than $0.5^{\circ} \mathrm{C}$ (or less than $-0.5^{\circ} \mathrm{C}$ ) subject to the constraint that the area of the warm anomaly is greater than the Niño 3.4 region. $\mathrm{CHI}$ longitude is the temperature-weighted center of this warm anomaly. The search domain is the equatorial Pacific (from $120^{\circ} \mathrm{E}$ to $70^{\circ} \mathrm{W}$ and from $5^{\circ} \mathrm{S}$ to $5^{\circ} \mathrm{N}$ ). By our definition to qualify as an El Niño event the CHI amplitude must exceed $0.5^{\circ} \mathrm{C}$ for 5 consecutive months. To qualify as a La Niña event the $\mathrm{CHI}$ amplitude has to be less than $-0.5^{\circ} \mathrm{C}$ for 5 consecutive months.

\section{Results}

[13] We begin our analysis by comparing the CHI to the SST anomaly averaged over the Niño 3.4 region. The Niño 3.4 region spans from $170^{\circ} \mathrm{W}-120^{\circ} \mathrm{W}$ and from $5^{\circ} \mathrm{S}-5^{\circ} \mathrm{N}$. Figure 1 shows the CHI amplitudes for El Niño and La Niña events compared to the Niño 3.4 index. The CHI amplitude and the Niño 3.4 index show high correlation for both El Niño $(r=0.9)$ and La Niña $(r=0.8)$ conditions. Figures $1 \mathrm{a}$ and $1 \mathrm{~b}$ show that the CHI tends to be greater than Niño 3.4 SST anomaly for weak events, and tends to be less than Niño 3.4 SST anomaly for strong events. This is due to the fact that El Niño strength is correlated with the area of warming [Giese and Ray, 2011]. Weak, and therefore often small, events are unlikely to span across the entire Niño 3.4 index, and so the Niño 3.4 region under-represents the strength of the event. Alternatively, strong, and therefore large events, likely encompass an area greater than the Niño 3.4 region. Since the Niño 3.4 region represents a subset of the warming temperature anomalies in this region likely over-represents the strength of the event. Although the $\mathrm{CHI}$ metric is used as an alternate to Niño 3.4 index, the high correlation with the index show excellent agreement of El Niño and La Niña strengths between the two indices.

\subsection{Comparison With ERSST, HadISST, and Kaplan SST}

[14] One way to evaluate the historical ocean reanalysis is to compare ENSO in the reanalysis with previously published SST reconstructions. The CHI amplitude for SODA and the three reconstructions is shown in Figure 2. Variability in the strength of CHI-amplitude for El Niño from ERSST v3 (Figure 2b) and HadISST (Figure 2c) resemble very closely the variability in the strength of CHI amplitude of El Niño from SODA 2.2.4. Both ERSST v3 and HadISST show strong El Niño periods in the late nineteenth and the late twentieth century with weaker events in between, similar to those in SODA 2.2.4. However, CHI amplitude in Kaplan v2 (Figure 2d) shows stronger El Niños in the late twentieth century.

[15] A comparison of CHI amplitude for El Niño events between the reconstructed SST and SODA 2.2.4 shows how 

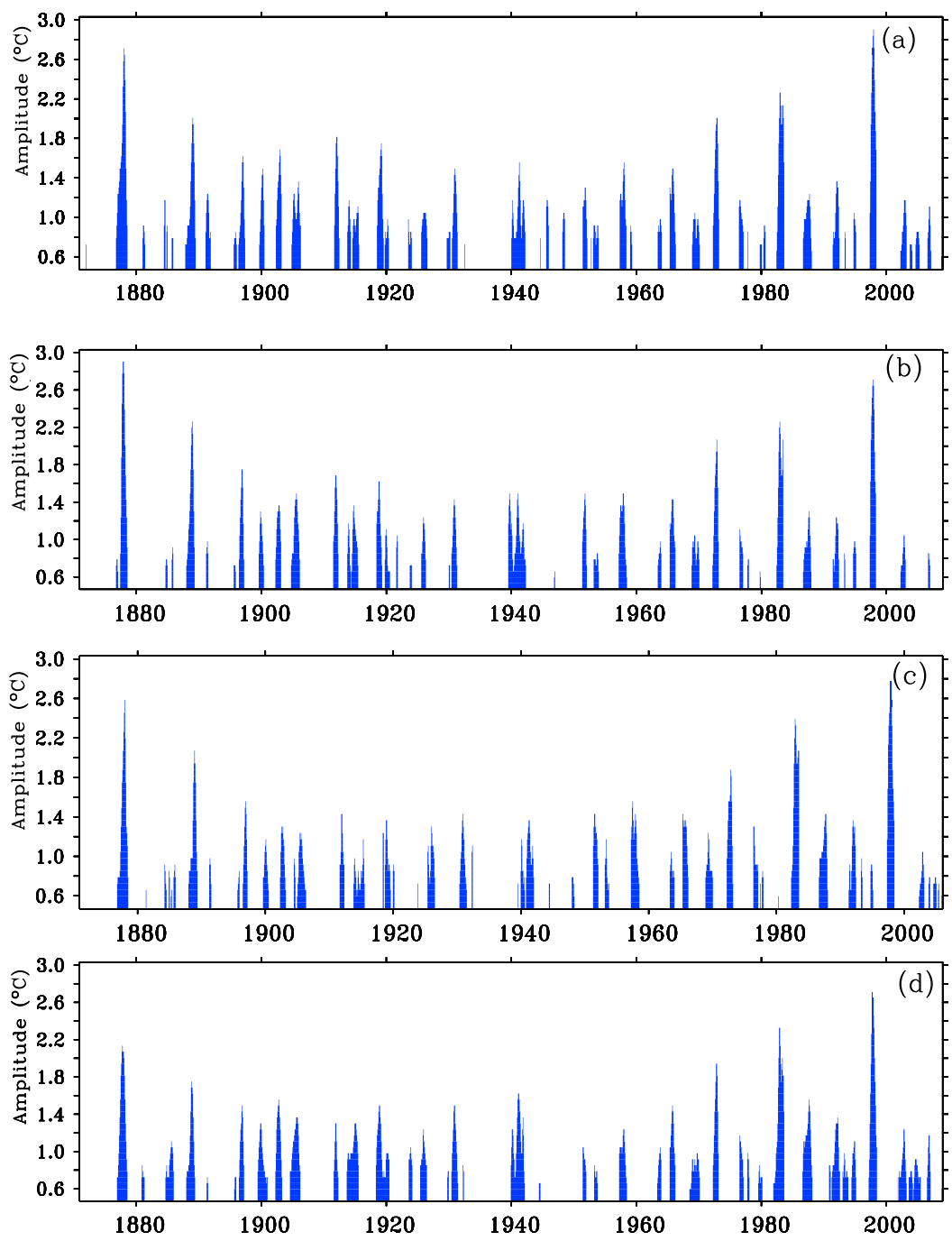

Figure 2. CHI amplitude for SST anomalies greater than $0.5^{\circ} \mathrm{C}$ constructed from (a) SODA 2.2.4, (b) ERSST v3, (c) HadISST, and (d) Kaplan v2.

different the products are in terms of measuring the strength of El Niño. The lower panel of Figure 3a shows a high correlation between the CHI amplitudes of ERSST and SODA 2.2.4. To distinguish the products for periods of varying density of observations, the data sparse periods (1871-1949) are plotted in red and the data dense periods (1950-2008) are plotted in blue (Figure 3). The CHI amplitudes from ERSST and SODA 2.2.4 agree very well during periods of dense observations (0.96) as well as during periods of sparse observations (0.76). Even with HadISST CHI amplitudes for El Niño show high correlation with that from SODA 2.2.4 during both periods (0.94 and 0.78) (Figure 3b). CHI amplitude from Kaplan v2 shows a correlation of 0.94 with SODA 2.2.4 for the data dense period and 0.68 for data sparse period (Figure 3c). Overall, SODA 2.2.4 shows better agreement with ERSST than either HadISST or Kaplan v2. The strength of La Niña events in SODA 2.2.4 correlates best with ERSST v3 (0.85) followed by HadISST (0.78) and Kaplan v2 (0.74) in the data dense periods (Figure 4).

[16] A similar comparison, but for $\mathrm{CHI}$ longitude, shows differences in the location of the center of warming. During periods of dense observations the $\mathrm{CHI}$ longitude from
ERSST and SODA 2.2.4 is correlated at 0.87 for warm events (Figure 3a). El Niño locations in SODA 2.2.4 are well correlated to those in HadISST at 0.77 during periods of dense observations, although during periods of sparse observations they are nearly uncorrelated (Figure $3 b$ ). Figure $3 c$ shows a similar relationship for CHI longitudes from Kaplan v2. El Niño locations in SODA 2.2.4 are also well correlated with Kaplan v2 (0.82), although only during the data dense period. The difference in $\mathrm{CHI}$ longitude between the reconstructions and SODA 2.2.4 is prominent west of $140^{\circ} \mathrm{W}$ in the centralwestern Pacific. This is likely due to the method used in reconstructing SST data in data sparse periods. As for El Niño events, the location of La Niña events in SODA 2.2.4 are less well correlated with ERSSTv3 (0.51), HadISST (0.58), and Kaplan v2 (0.65) during data sparse periods, but are better correlated in data dense periods ( 0.85 with ERSST v3, 0.85 with HadISST and 0.89 with Kaplan v2).

[17] The debate over the long-term variability in the position of El Niño warming therefore becomes complicated using the reconstructed data products. Although the strengths of the El Niño are comparable between the reanalysis and the reconstructions the locations of warming diverge significantly. 
(a)
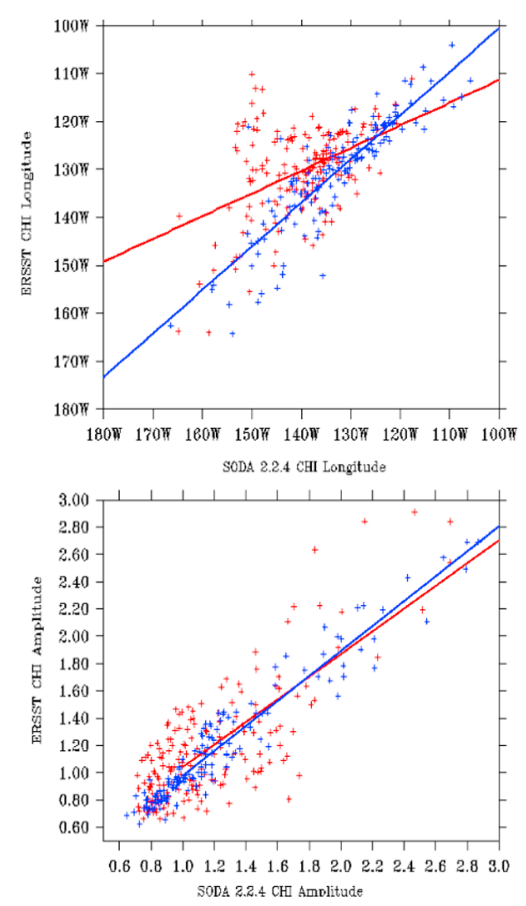

(b)
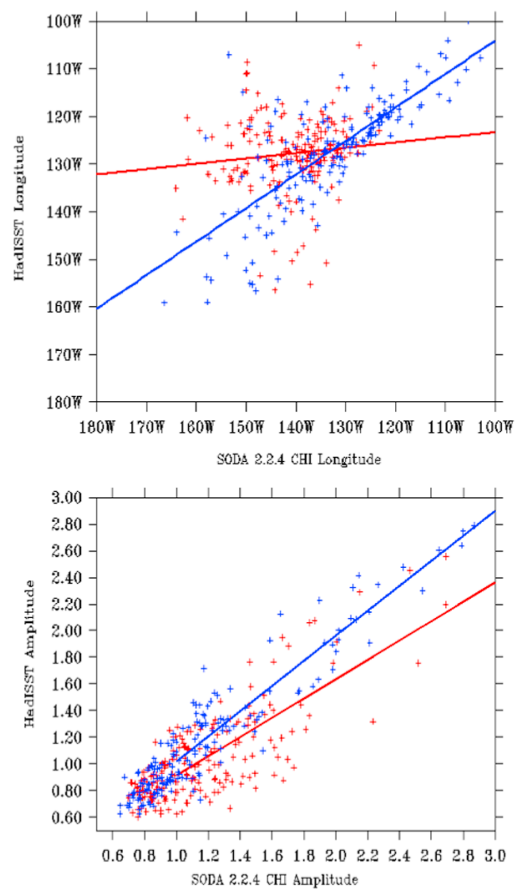

(c)
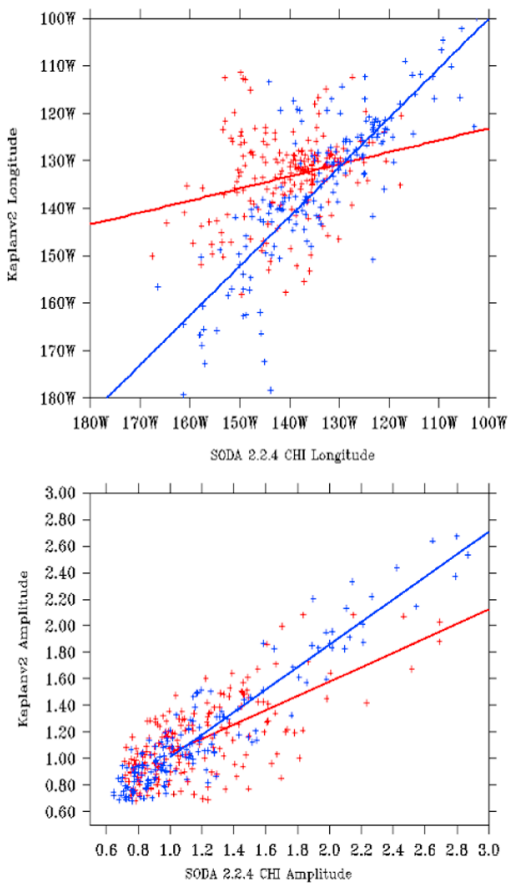

Figure 3. (top) CHI longitude from (a) ERSST v3, (b) HadISST, and (c) Kaplan v2 plotted as a function of CHI longitude from SODA 2.2.4 for warm events. The correlation coefficients for the periods 1871-1949 and 1950-2008 for ERSST v3 are 0.46 and 0.87, for HadISST are 0.16 and 0.77, and for Kaplan v2 are 0.25 and 0.82 , respectively. (bottom) Same as Figure 3 (top), but for CHI amplitude plotted as a function of CHI amplitude from SODA 2.2.4. The correlation coefficients for the periods 1871-1949 and 1950-2008 for ERSST v3 are 0.76 and 0.96, for HadISST are 0.78 and 0.94, and for Kaplan v2 are 0.68 and 0.94, respectively. Values from 1871 through 1949 are shown in red and values from 1950 through 2008 are shown in blue. The least squares regression for both periods of time are shown as a solid line.

The mean location of CHI longitude of El Niño events in ERSST $\left(130^{\circ} \mathrm{W}\right)$ and HadISST $\left(127^{\circ} \mathrm{W}\right)$ is east of that in SODA 2.2.4 $\left(139^{\circ} \mathrm{W}\right)$. The mean location of $\mathrm{CHI}$ longitude in SODA 2.2.4 $\left(139^{\circ} \mathrm{W}\right)$ and SODA 2.2.0 $\left(143^{\circ} \mathrm{W}\right)$ differ at most by $4^{\circ}$. Notably the standard deviation of $\mathrm{CHI}$ longitude in ERSST (10.8) and HadISST (10.9) compared to SODA 2.2.4 (12.5) and SODA 2.2.0 (14.5) indicates a more localized occurrence of El Niño in ERSST and HadISST compared to the reanalysis. The distributions of $\mathrm{CHI}$ longitude are negatively skewed in ERSST $(-0.65)$ and in HadISST $(-0.56)$, which is in contrast to that in SODA 2.2.4 (0.1). This implies that the center of the warm anomaly during El Niño is further east in the reconstructions when compared to the reanalysis. An interesting observation here is that the distributions from ERSST v3 and HadISST failed the Lilliefors test, which tests the null hypothesis of whether two distributions are from the same family of Gaussian curves. Thus the null hypothesis that the distributions cannot be distinguished from a Gaussian has to be rejected. This implies that the El Niño location in ERSST v3 and HadISST could not be considered to have a single mean longitude about which all other El Niño locations are randomly distributed.

[18] Figure 5 shows histograms of CHI longitude of El Niño events from SODA 2.2.4, ERSST, and HadISST for periods of sparse observations (1871-1949) and periods of dense observations (1950-2008) separately. The distribution of CHI longitude from SODA 2.2.4 during the two periods 1871-1949 (Figure 5a) and 1950-2008 (Figure 5d) do not look similar and the mean location of $\mathrm{CHI}$ longitudes differ by $6^{\circ}$. The mean location of $\mathrm{CHI}$ longitude during the two periods of 1871-1949 (Figure 5b) and 1950-2008 (Figure 5e) differ only by one degree in both ERSST and HadISST. That the location of ENSO is so similar in the two periods may be due to the computed EOF pattern of SST from the data dense periods (1950-2005) that was used to reconstruct SST data in the data sparse periods (1871-1949). The SST reconstructions in data sparse periods could thus be dominated by the strong El Niño events of 1982-83 and 1997-98, which could result in the sharp peak in the CHI longitude histograms with low standard deviations.

\subsection{ENSO Frequency, Duration, and Direction of Propagation}

[19] In a recent paper Giese and Ray [2011] show that there is prominent decadal variability in ENSO strength and location during the twentieth century, but there is little overall trend in either. We extend that work by looking for trends in ENSO frequency, duration, and direction of propagation.

\subsubsection{ENSO Frequency}

[20] Figure 6 shows the occurrence of El Niño and La Niña during the period 1871-2008 in terms of the elapsed time between consecutive events. The longest elapsed time 
(a)
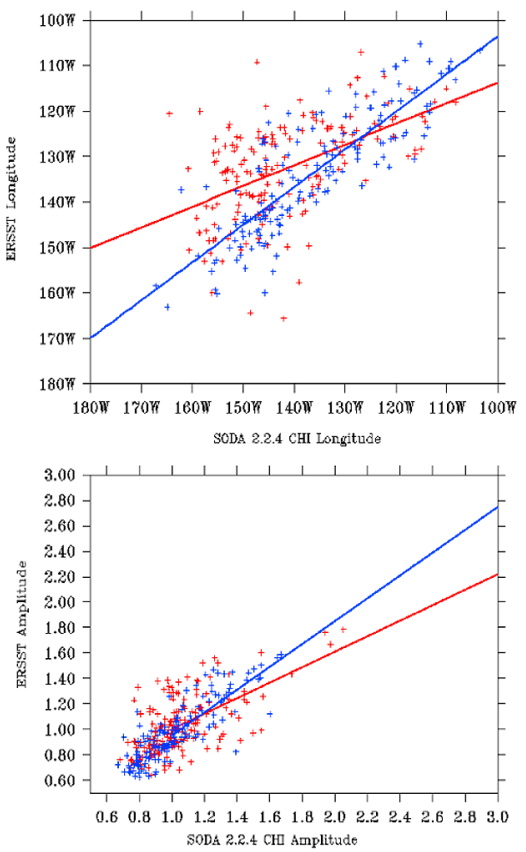

(b)
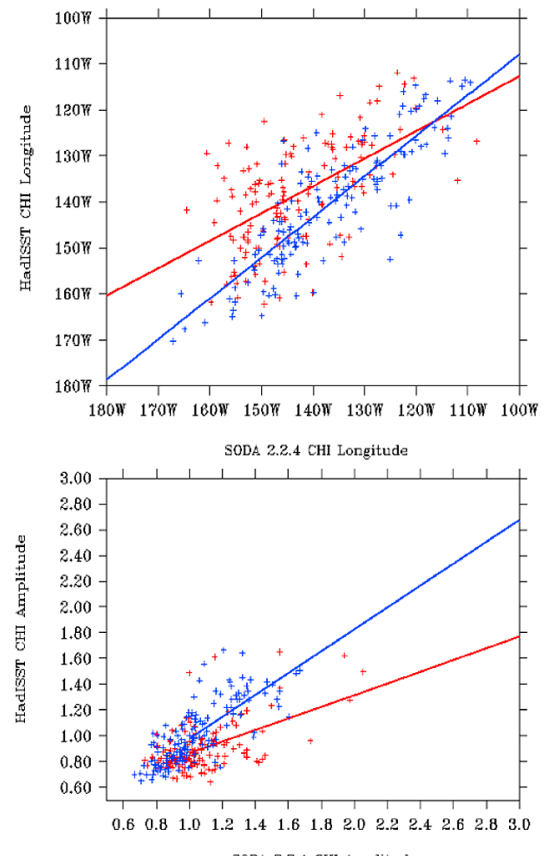

(c)
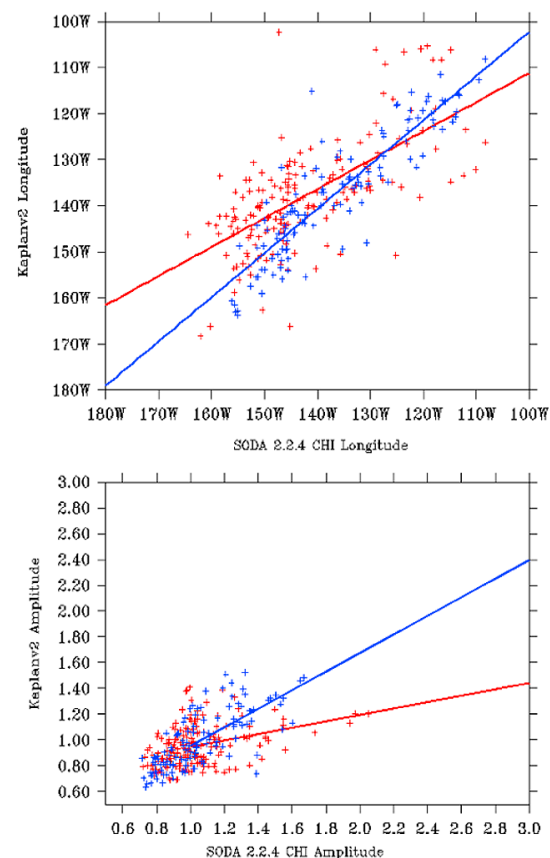

Figure 4. (top) CHI longitude from (a) ERSST v3, (b) HadISST, and (c) Kaplan v2 plotted as a function of CHI longitude from SODA 2.2.4 for cold events. (bottom) Same as Figure 4 (top), but for CHI amplitude plotted as a function of CHI amplitude from SODA 2.2.4. Values from 1871 through 1949 are shown in red and values from 1950 through 2008 are shown in blue. The least squares regression for both periods of time are shown as a solid line.

(120 months) occurs between the El Niño of 1929/31 and the El Niño of 1940/42. There were frequently occurring El Niños during the late nineteenth century and the beginning of the twentieth century, during the 1950s, and during the end of the twentieth century. Overall there is no clear trend in the frequency of El Niño. The distribution of the frequency of El Niño has a mean of 3.9 years (46.6 months) with a standard deviation of 1.9 years (22.8 months). Using the Lilliefors test the distribution of wait times of El Niño events cannot be distinguished from a Gaussian with a p-value of 0.12 and a test statistic of 0.14 .

[21] One question that arises is how many events are required to detect a change in ENSO frequency. Using statistical tests we calculate the minimum number of events required to reliably determine a change in the mean wait time (frequency) of El Niño events at the $95 \%$ confidence level. Consider two normally distributed populations of wait times of El Niño events. The first population represents ENSO as it has been in the past. This distribution has $\mathrm{n}_{1}$ events (in our case this is the 34 ENSO events from 1871 to 2008) with a mean wait time of $\mathrm{m}_{1}$ months and with a standard deviation of $\sigma_{1}$. Using the SODA record $\mathrm{m}_{1}$ is 46.6 months and $\sigma_{1}$ is 22.8 months. We wish to find how many events $\left(\mathrm{n}_{2}\right)$ are required to detect a change $(\delta)$ in the frequency from $\mathrm{m}_{1}$ to $\mathrm{m}_{2}$ at the $5 \%$ significance level. We calculate $\mathrm{n}_{2}$ using the Student's t-test for $\delta=4$ months, $\delta=8$ months, and $\delta=12$ months. We assume that the standard deviation of the second population is the same as it has been in the past $\left(\sigma_{2}=\sigma_{1}\right)$. The Student's t-test returns 42 events $\left(\mathrm{n}_{2}=42\right)$ that would be needed to reliably detect a change in the mean frequency of
8 months and 251 events $\left(n_{2}=251\right)$ to detect a change in the mean frequency of 4 months at the $5 \%$ significance level.

[22] Table 1 shows the number of events $\left(\mathrm{n}_{2}\right)$ needed for different changes in the mean frequency $(\delta)$ of events and for varied standard deviations $\left(\sigma_{2}\right)$ at a $5 \%$ significance level. The table shows that as the standard deviation of the distribution of the second sample decreases, the number of events required detecting the same change in the mean frequency decreases as well. For simplicity, the distribution of wait time for the second sample, which can be interpreted as the excess number of events needed to detect a change in the mean frequency is the same as that for the 34 El Niño events in the reanalysis. However, such an assumption is not flawless, as the distribution of wait times between events can change. The analysis shows that $34 \mathrm{El}$ Niño events (if not fewer) in 138 years are not sufficient to identify a change in the mean frequency of El Niño events. Enfield and Cid [1991] performed a similar statistical analysis of multicentury climate data to show that El Niño frequency had not changed since 1525. Figure $6 \mathrm{~b}$ shows the corresponding frequency of La Niña events from 1871 to 2008 in terms of the wait time between consecutive La Niña events. The intervals between consecutive La Niña events are more widely distributed than for El Niño events. After 1976 there are fewer La Niña events that occur after longer waiting times compared to El Niño events. The mean frequency of La Niña is 55.6 months ( $\sim 5$ years) and the standard deviation of the frequency for La Niña is 29 months ( $\sim 2.5$ years). Both the mean and standard deviation for La Niña events are larger than for El Niño events. 

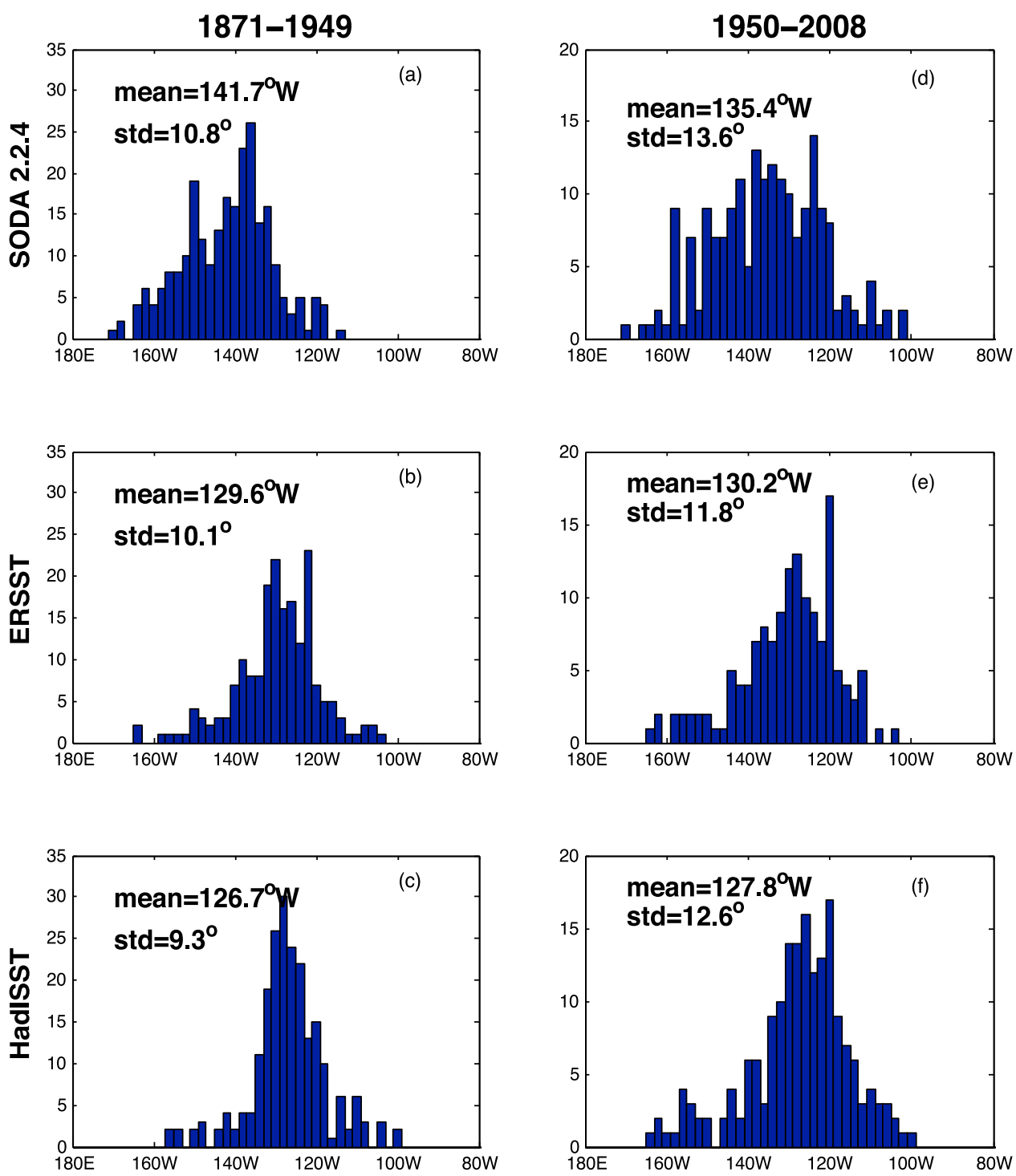

Figure 5. Histograms of CHI longitude for El Niño events shown separately for (a, b, c) 1871-1949 and for (d, e, f) 1950-2005 periods as constructed from SODA 2.2.4 (Figures 6a and 6d), ERSST (Figures 6b and 6e), and HadISST (Figures 6c and 6f). The distribution of location of El Niño events is shown in each plot with the mean location.

\subsubsection{ENSO Duration}

[23] Figure 7a shows the variation in the duration of El Niño events from 1871 to 2008 . The duration of an event is taken to be the number of consecutive months for which CHI amplitude is greater than or equal to $0.5^{\circ} \mathrm{C}$. The mean duration for El Niño events is 12.4 months with a standard deviation of 5.7 months. The duration of El Niño is highly variable ranging from just 5 months (1881, 1945, 1948, 1994/95, $2003 / 04)$ to as long as 27 months (1940-42). Interestingly, the longest event is the El Niño of 1940-42, which occurred after a period of 10 years without an El Niño. The El Niños before the 1940-42 warming tend to cluster either at long duration (about 2 years) or short duration (about 10 months). After the El Niño of 1940-42 most of the El Niño events were of approximately one year in duration.

[24] Figure $7 b$ shows the duration of La Niña events over the 138-year record of study. The time series of duration shows that both short-lived and long-lived La Niña events occur consistently throughout the record. The mean duration for La Niña events is 15.2 months with a standard deviation of 8 months. The duration of La Niña is also highly variable ranging from 5 months $(1876,1945)$ to as many as 30 months (1998-2000). Earlier we noted that the period between 1930 and 1940 experienced weak La Niña events; Figure 7b shows that during this time the duration of La Niña is short as well. Comparing Figure $7 \mathrm{a}$ and Figure $7 \mathrm{~b}$ shows that in recent years short duration El Niño events occur whereas the duration of La Niña is generally long. Overall the mean duration of La Niña events is longer than the mean duration of El Niño events. Okumura and Deser [2010] suggests that the influence of the Indian Ocean on wind anomalies in the western equatorial Pacific is a possible cause of the asymmetry in the duration of El Niño and La Niña. Okumura et al. [2011] demonstrate this hypothesis using AGCM experiments and 

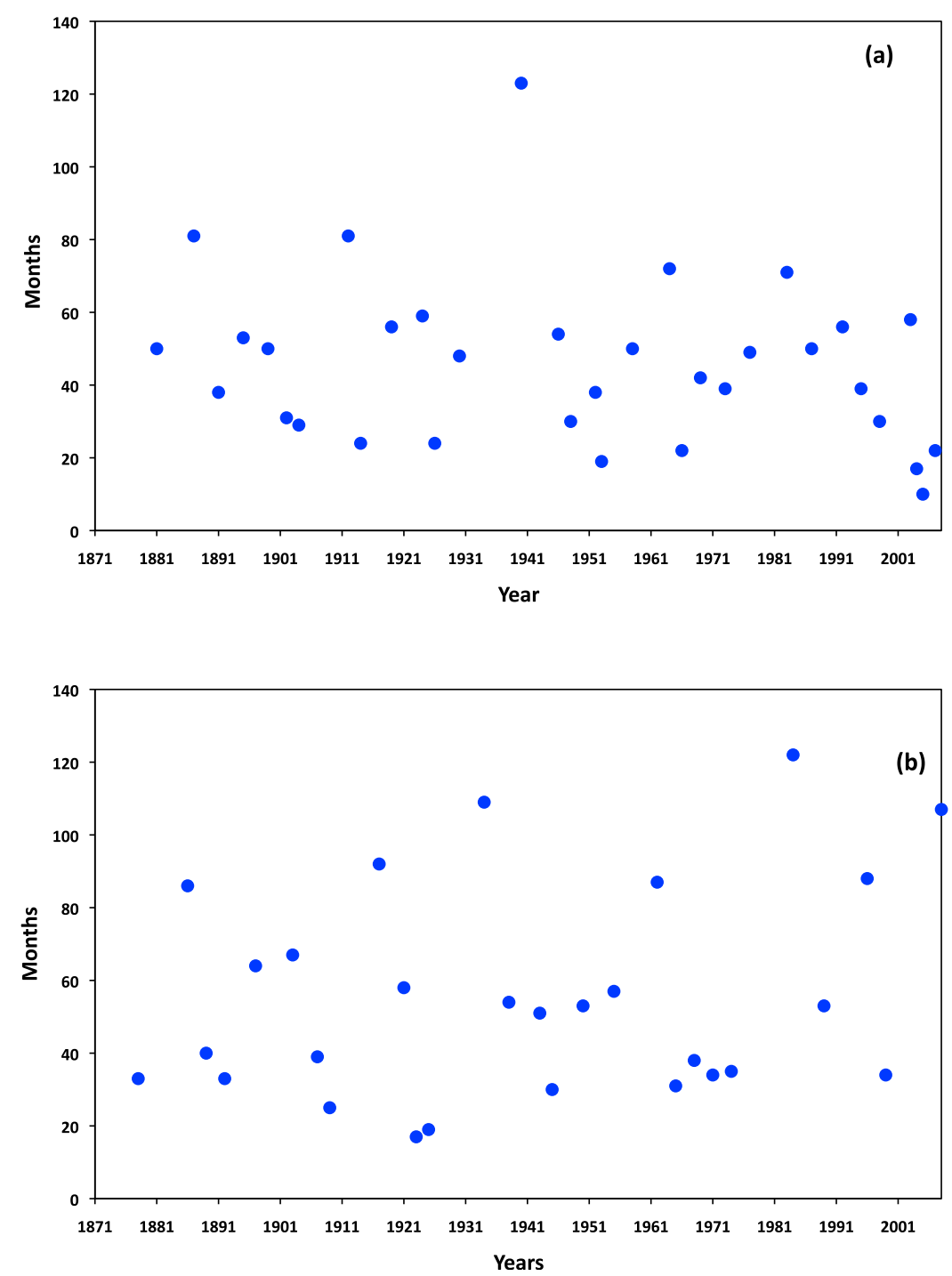

Figure 6. Number of months since the preceeding (a) El Niño and (b) La Niña events over the period 1871-2008.

show an additional contribution of off-equatorial winds that influence SST anomalies in the equatorial Pacific.

\subsubsection{ENSO Direction of Propagation}

[25] Fedorov and Philander [2001] propose a theory to explain eastward and westward propagating anomalies of El Niño. They argue that a deep thermocline with weak background winds favors eastward propagation and a shallow thermocline with strong background winds favors a westward propagation. McPhaden and Zhang [2009] explore the direction of El Niño propagation for the period from 1950 to 2008. They use the Reynolds et al. [2002] blended satellite and in situ SST analysis for the period 1981-2008 and the Smith et al. [2008] in situ SST analysis for the period 19501981 to show that a change in the phase propagation of SST anomalies during El Niño from westward to eastward occurred after the mid-1970s. Their analysis shows little change in phase propagation of La Niña. Figure 8a shows a composite of the 34 El Niños from SODA 2.2.4 for the period from 1871 to 2008 . The first indication of positive anomalies occurs in early year 0 with weak anomalies near the Dateline that propagate eastward. However, anomalies greater than $0.5^{\circ} \mathrm{C}$ seem to have a weak westward propagation. From the composite of the entire record there does not seem to be a significant propagation of anomalies during El Niño. Figure $8 \mathrm{~b}$ shows the composite over the period 1980-2008; the period examined by McPhaden and Zhang [2009]. This composite shows weak warm anomalies from

Table 1. Number of El Niño Events $\left(n_{2}\right)$ Needed to Determine a Change in the Period of El Niño ${ }^{a}$

\begin{tabular}{cccc}
\hline Standard Deviation & \multicolumn{3}{c}{ Number of Events $=\mathrm{n}_{2}$} \\
\hline$\sigma_{2}$ & $\mathrm{~m}_{2}=50.6$ & $\mathrm{~m}_{2}=54.6$ & $\mathrm{~m}_{2}=58.6$ \\
& $\left(\delta_{1}=4\right)$ & $\left(\delta_{2}=8\right)$ & $\left(\delta_{3}=12\right)$ \\
34.8 & 602 & 114 & 14 \\
22.8 & 251 & 42 & 3 \\
10.8 & 92 & 22 & 3 \\
\hline
\end{tabular}

${ }^{\mathrm{a}}$ The number of events $\left(\mathrm{n}_{2}\right)$ is shown for different mean wait times $\left(\mathrm{m}_{2}\right)$ and different standard deviations $\left(\sigma_{2}\right) ; \delta_{1}, \delta_{2}$ and $\delta_{3}$ represent the change in the mean frequency of El Niño. 

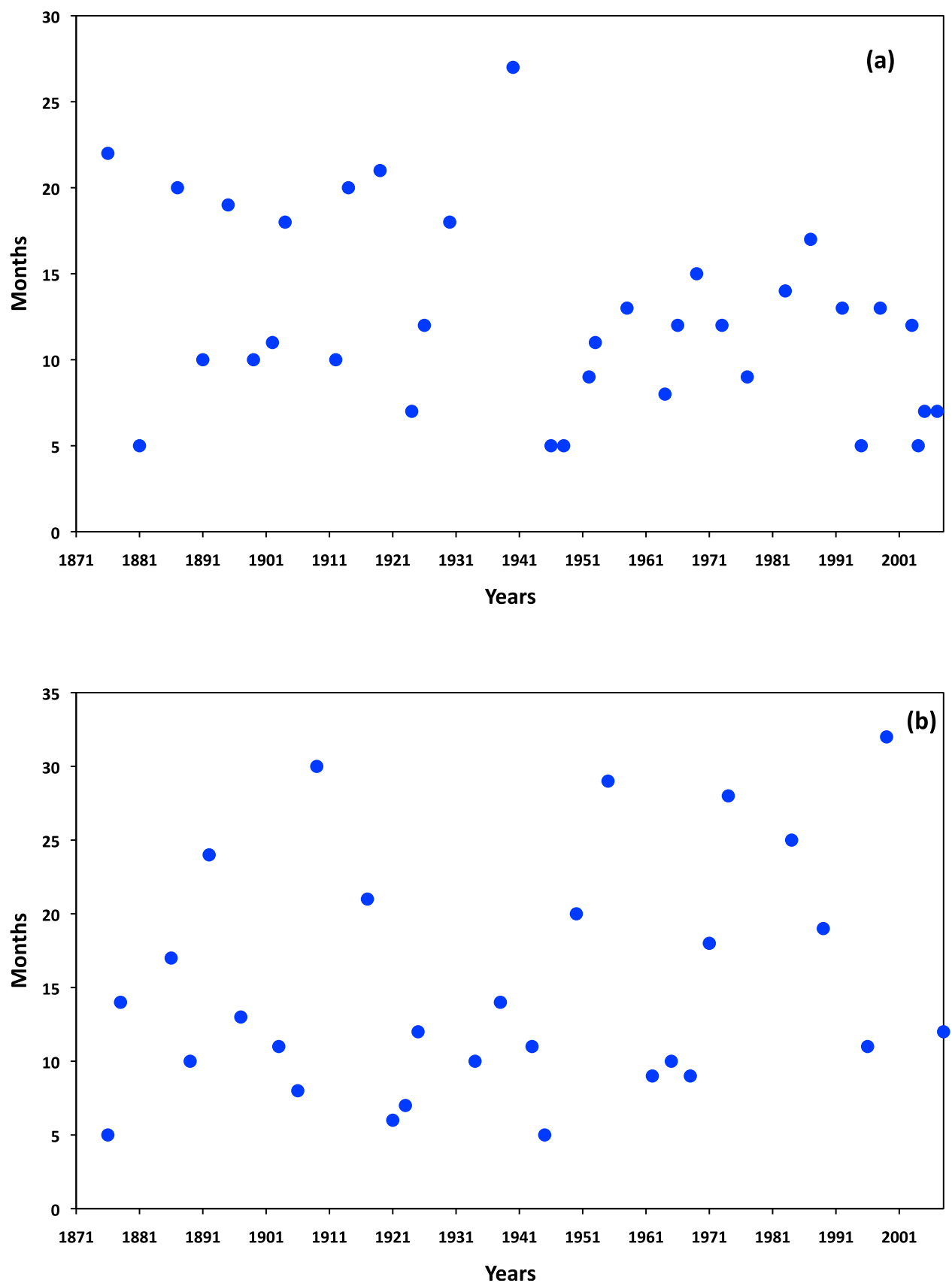

Figure 7. Duration of (a) El Niño and (b) La Niña events in months during 1871-2008. Dots locate the year of the event and indicate the number of months the warm anomaly $\left(>0.5^{\circ} \mathrm{C}\right)$ (Figure $7 \mathrm{a}$ ) or the cold anomaly $\left(<-0.5^{\circ} \mathrm{C}\right)$ (Figure $\left.7 \mathrm{~b}\right)$ persist.

year -1 near the Dateline, which then propagate eastward during the middle of year 0 . The warmest anomalies show negligible phase propagation. Figure 8c shows the composite of SST anomalies for 1950-1976, which was also analyzed by McPhaden and Zhang [2009]. During this period the composite shows a westward propagating anomaly in agreement with McPhaden and Zhang [2009]. Figure 8d shows the composite of El Niño for the period 1871-1941. This period shows eastward propagation of anomalies warmer than $0.5^{\circ} \mathrm{C}$ west of $160^{\circ} \mathrm{W}$. However, the anomalies across the equatorial Pacific basin appear to start and end simultaneously during the period.
[26] The surface anomaly is directly influenced by the wind anomaly above to the first order. The composite of zonal wind anomalies during El Niño events for the four periods is shown in Figure 9. During the period from 1871 to 2008 there is a prominent eastward zonal phase propagation of westerly wind anomalies. Similar eastward phase propagation is seen in the composites of 1980-2008 (Figure 9b) and 1871-1941 (Figure 9d). However, the composite of events from 1950 to 1976 (Figure 9c) show westerly wind anomalies moving eastward west of the Dateline and moving westward east of the Dateline. 

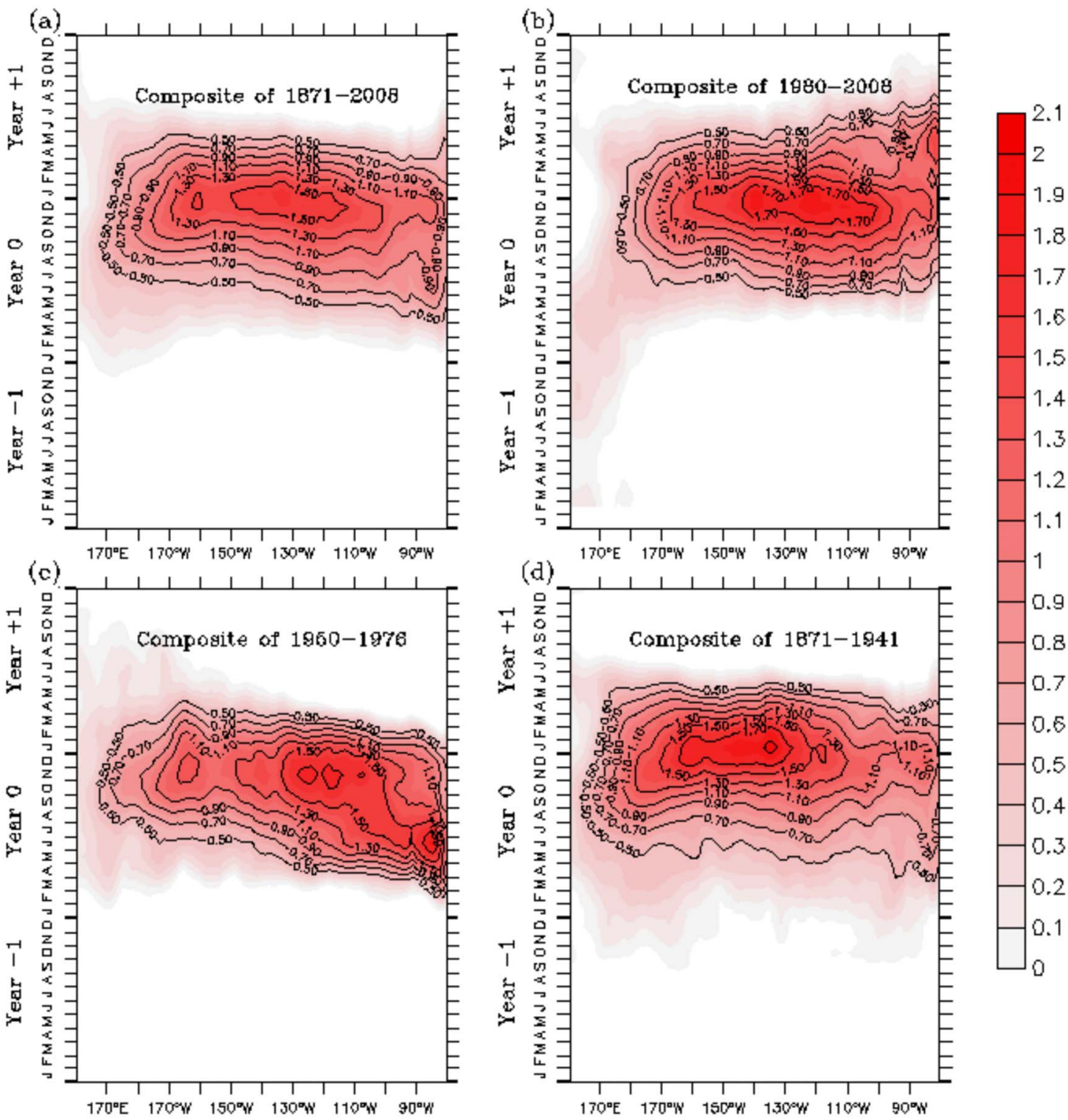

Figure 8. Composite time evolution of SST anomalies during El Niño averaged from $5^{\circ} \mathrm{S}$ to $5^{\circ} \mathrm{N}$. Composites of El Niño during (a) 1871-2008, (b) 1980-2008, (c) 1950-1976, and (d) 1871-1941. Anomalies greater than $0^{\circ} \mathrm{C}$ are shaded, and anomalies greater than $0.5^{\circ} \mathrm{C}$ are contoured at an interval of $0.2^{\circ} \mathrm{C}$.

[27] Figure 10a shows the composite SST anomaly for La Niña events over a span of four years during 18712008. The composite shows a slight westward propagation of anomalies colder than $-0.5^{\circ} \mathrm{C}$ although normal conditions return simultaneously across the basin. Figure $10 \mathrm{~b}$ shows the composite of SST anomalies for La Niña event during the period 1980-2008. During this time there is a prominent reappearance of cold anomalies in the end of year +1 . This elongates the duration of La Niña events during this period further as is also evident in Figure 7b. Figure 10c shows the composite of anomalies of SST for La Niña during 19501976. This period shows a clear westward propagation of cold anomalies. Figure 10d shows the composite of SST anomalies for La Niña events during 1871-1949. The period also shows westward propagating anomalies. The westward zonal phase propagation of SST anomalies during La Niña is evident in all the composites.

\subsection{Subsurface ENSO}

[28] One of the advantages of having reanalysis data is that it contains a representation of the subsurface that is not available from a SST analysis. The center of warming in the subsurface is examined to measure the subsurface anomalies and their location during El Niño. Since subsurface anomalies are larger than surface anomalies a two-dimensional CHI of the subsurface was constructed for anomalies greater than $1{ }^{\circ} \mathrm{C}$. The search region for the subsurface $\mathrm{CHI}$ is between $120^{\circ} \mathrm{E}$ to $70^{\circ} \mathrm{W}$ and between 0 and $400 \mathrm{~m}$ of depth. The three metrics for measuring the subsurface warm anomaly during El Niño are the amplitude of the subsurface warming 

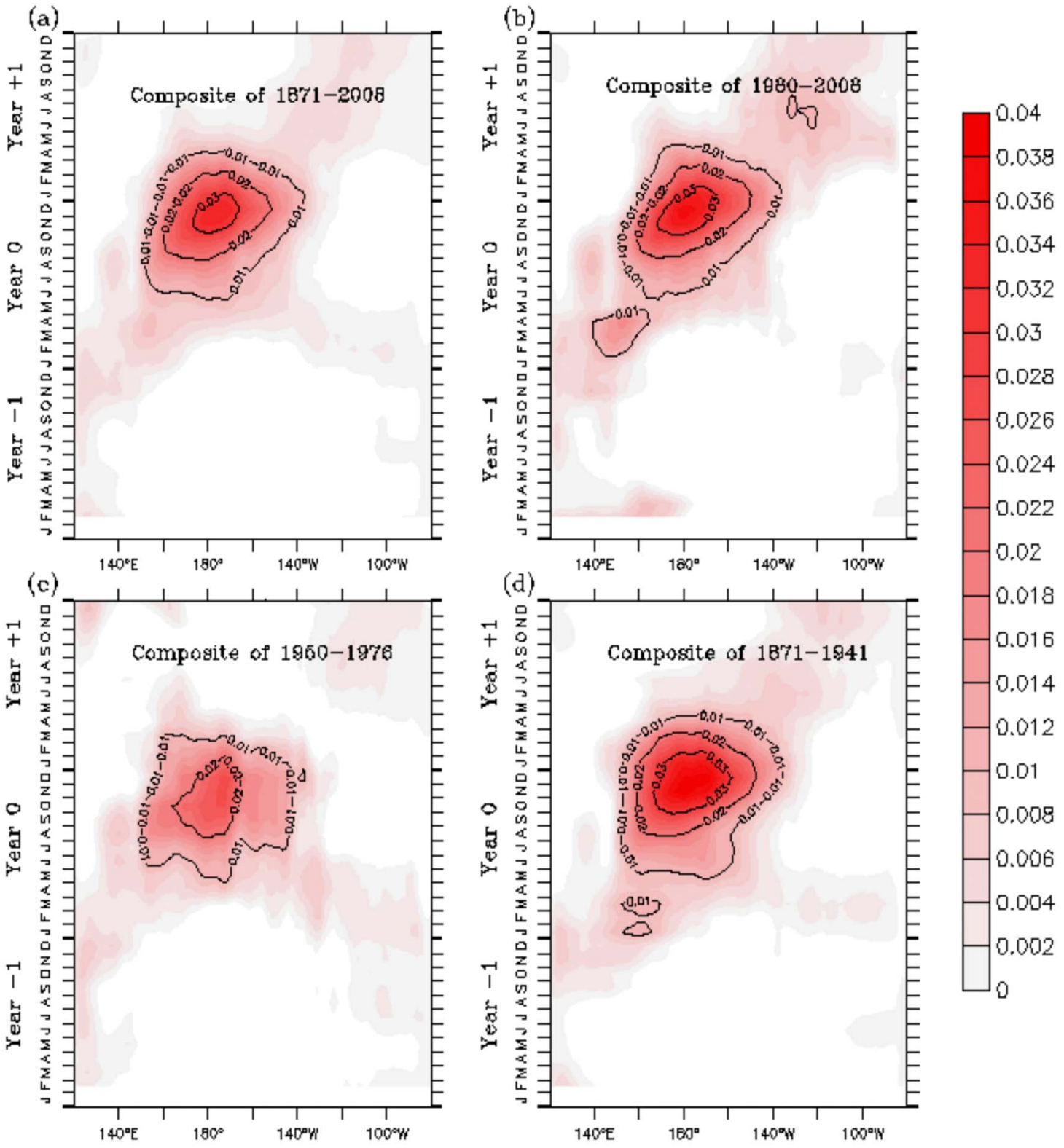

Figure 9. Composite time evolution of zonal wind stress anomalies during El Niño at the equator. Composites are for El Niño during (a) 1871-2008, (b) 1980-2008, (c) 1950-1976, and (d) 1871-1941. Westerly zonal wind anomalies are shaded, and anomalies greater than $0.01 \mathrm{dynes} / \mathrm{cm}^{2}$ are contoured at an interval of 0.01 dynes $/ \mathrm{cm}^{2}$.

(CHI amplitude), the longitudinal location of the warming (CHI longitude), and the depth of the center of warming (CHI depth). The subsurface CHI amplitude has a mean of $1.8^{\circ} \mathrm{C}$ with a standard deviation of $0.5^{\circ} \mathrm{C}$ and a skewness of 1.14 , which are close to the values of CHI amplitude for SST. The subsurface $\mathrm{CHI}$ longitude has a mean at around $127^{\circ} \mathrm{W}$, which is east of the mean location of surface $\mathrm{CHI}$ longitude $\left(139^{\circ} \mathrm{W}\right)$ and has a smaller standard deviation of $11.6^{\circ}$ than the surface CHI longitude $\left(12.8^{\circ}\right)$. The mean depth of the subsurface CHI is $72 \mathrm{~m}$ and the maximum CHI depth is $120 \mathrm{~m}$.

[29] The long-term variation of the strength of subsurface warming during El Niño resembles that of surface warming. El Niños in the beginning of the record show strong subsurface warming, and strong warming occurs again at the end of the twentieth century (Figure 11a). The longitudinal location of subsurface El Niño warming does not show prominent variation over the record (Figure 11b). The depth of subsurface El Niño warming shows that there are shallower warm events in the late twentieth century. Figure 12a shows the subsurface $\mathrm{CHI}$ longitude as a function of surface $\mathrm{CHI}$ longitude. Although the subsurface $\mathrm{CHI}$ amplitude is well correlated to surface $\mathrm{CHI}$ amplitude $(0.83)$, a correlation of only 0.6 exists between the CHI longitudes. Figure $12 \mathrm{~b}$ shows the inter-metric correlation of CHI depth and CHI longitude for the subsurface. The mean depth of the $20^{\circ} \mathrm{C}$ isotherm is overlaid in red. This shows that the subsurface $\mathrm{CHI}$ are 

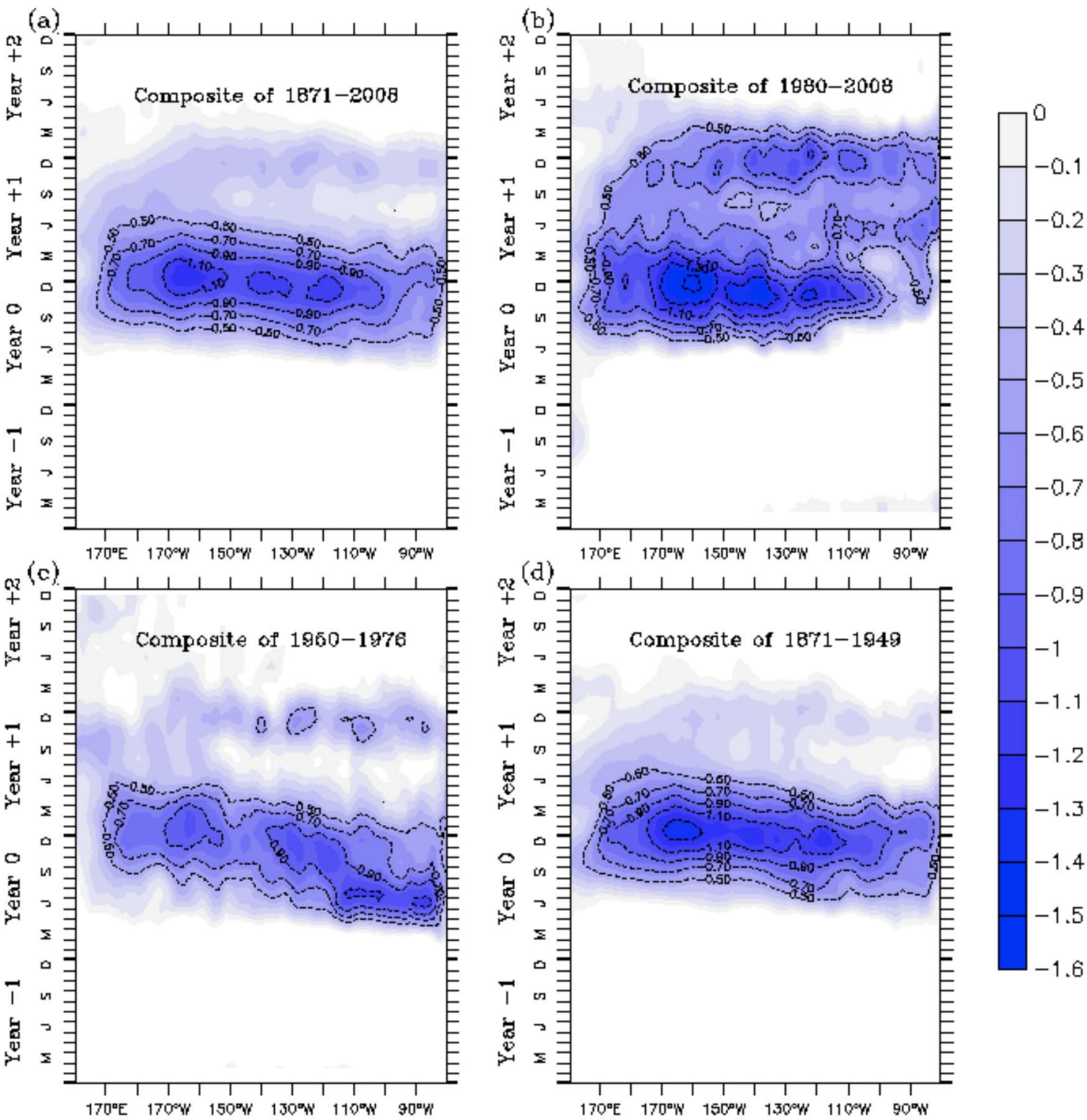

Figure 10. Composite time evolution of SST anomalies during La Niña averaged from $5^{\circ} \mathrm{S}: 5^{\circ} \mathrm{N}$. Composites here are for La Niña during (a) 1871-2008, (b) 1980-2008, (c) 1950-1976, and (d) 1871-1941. Anomalies less than $0^{\circ} \mathrm{C}$ are shaded, and anomalies less than $-0.5^{\circ} \mathrm{C}$ are contoured at an interval of $0.2^{\circ} \mathrm{C}$.

almost all located east of $170^{\circ} \mathrm{E}$ and have a depth that follows the mean depth of the $20^{\circ} \mathrm{C}$ isotherm (Figure 12b). Thus the depth of El Niño warming in the eastern Pacific is shallow, occurring near the $20^{\circ} \mathrm{C}$ isotherm, and thus contributes strongly to the surface warm anomaly. Vecchi and Soden [2007] use climate model experiments performed for the IPCC AR4 to show that the zonal tropical atmospheric circulation (Walker circulation) has weakened in recent years. This affects the tropical ocean circulation through reduced surface easterlies, a decreased mean depth of the equatorial thermocline and a reduced zonal equatorial thermocline slope. It is possible that with a reduced mean depth of the equatorial thermocline, an eastward propagating Kelvin wave prior to the peak phase of El Niño generates a strong warm anomaly in the subsurface, whose center of warming is closer to the surface. This may be the reason why El Niño events over the last few decades have a shallower center of warm anomaly, which has been further discussed by DiNezio et al. [2011].

\section{Summary and Conclusions}

[30] We explore changes in ENSO frequency, and duration, and direction of propagation using an ocean reanalysis that spans the period from 1871 to 2008. A comparison with three SST reconstructions shows that the reanalysis and the reconstructions agree well in the timing of ENSO events. There are differences in the strength of the events, with the reanalysis generally showing stronger ENSO events than in the reconstructions in the first half of the record. The reconstructions and the reanalysis show a centennial modulation in the strength of El Niño from late nineteenth century to late twentieth century. El Niño events in the late twentieth century 

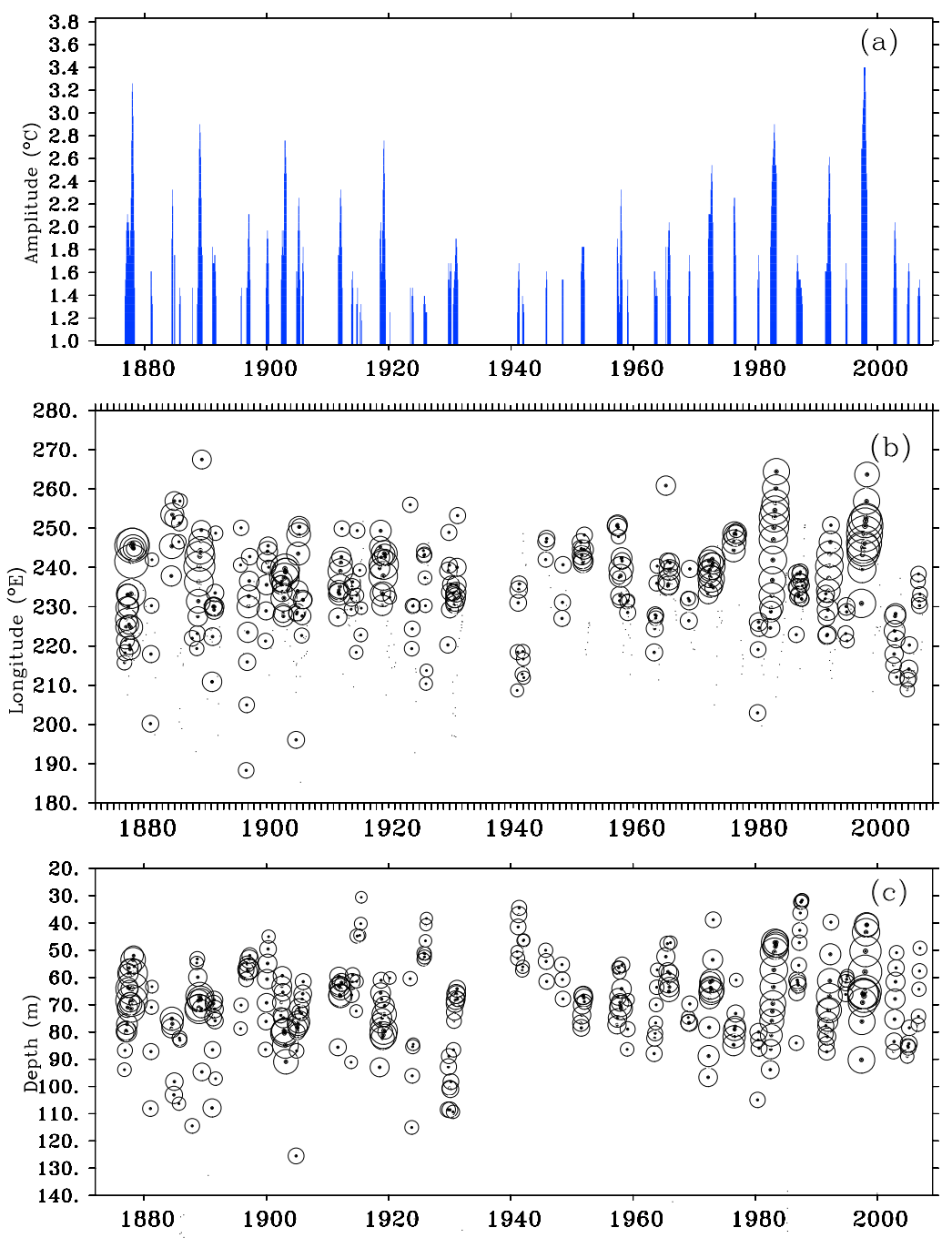

Figure 11. (a) The subsurface $\mathrm{CHI}$ amplitude (0-400 m) for El Niño events in ${ }^{\circ} \mathrm{C}$. (b) The subsurface CHI longitude from SODA 2.2.4 in degrees E longitude. (c) The subsurface CHI depth from SODA 2.2.4. In both Figures $11 \mathrm{~b}$ and $11 \mathrm{c}$ the size of the circle is proportional to the amplitude.

(during periods of global warming) are as strong as the events in the late nineteenth century and early twentieth century (periods of little global warming). The mid-twentieth century is dominated by weak El Niño events. A closer look indicates that the strong El Niños undergo distinct modulation in strength compared to weak El Niños. Weak events occur consistently throughout the record but strong warm events appear to be weakening in the early part of the record and strengthening in the late part of the record. The strength of El Niño from 1970 onward increases, however the trend over the entire period (1871-2008) is negligible. The strength of cold events does not have such prominent multidecadal variability. The results suggest that the variability in El Niño and La Niña strength is not due to anthropogenic global warming. However, there is prominent decadal modulation in El Niño strength, which could be part of its internal variability.

[31] Another feature of El Niño that is proposed to have changed due to global warming is its period. This study shows that the frequency of El Niño varies considerably over the record, with periods of time when ENSO occurs every other year to a period of almost ten years for which there is no El Niño event. For example, during the early twenty-first century there are frequent El Niño events and the period between 1930 and 1940 is distinct due to lack of El Niño. Periods before 1930 and after 1940 show a regular occurrence of El Niño events, however the mean frequency of El Niño does not change during the period of study. A statistical test is used to demonstrate that a population of 34 El Niño is too small to determine a change in the mean frequency of the events. Rather hundreds of events are required to determine a change in the mean frequency of El Niño. Thus the period is too short to determine if El Niño and La Niña are affected by anthropogenic climate change.

[32] There is a change in the duration of El Niño events from before 1931 to after 1941. Before $1931 \mathrm{El}$ Niño events were both long ( $\sim 20$ months) and short ( $\sim 10$ months), but after 1941 the duration of El Niño is more consistent, with duration of about 12 to 15 months. La Niña events generally last longer than El Niño events throughout the record. Recent cold events persist for long periods and are relatively few 

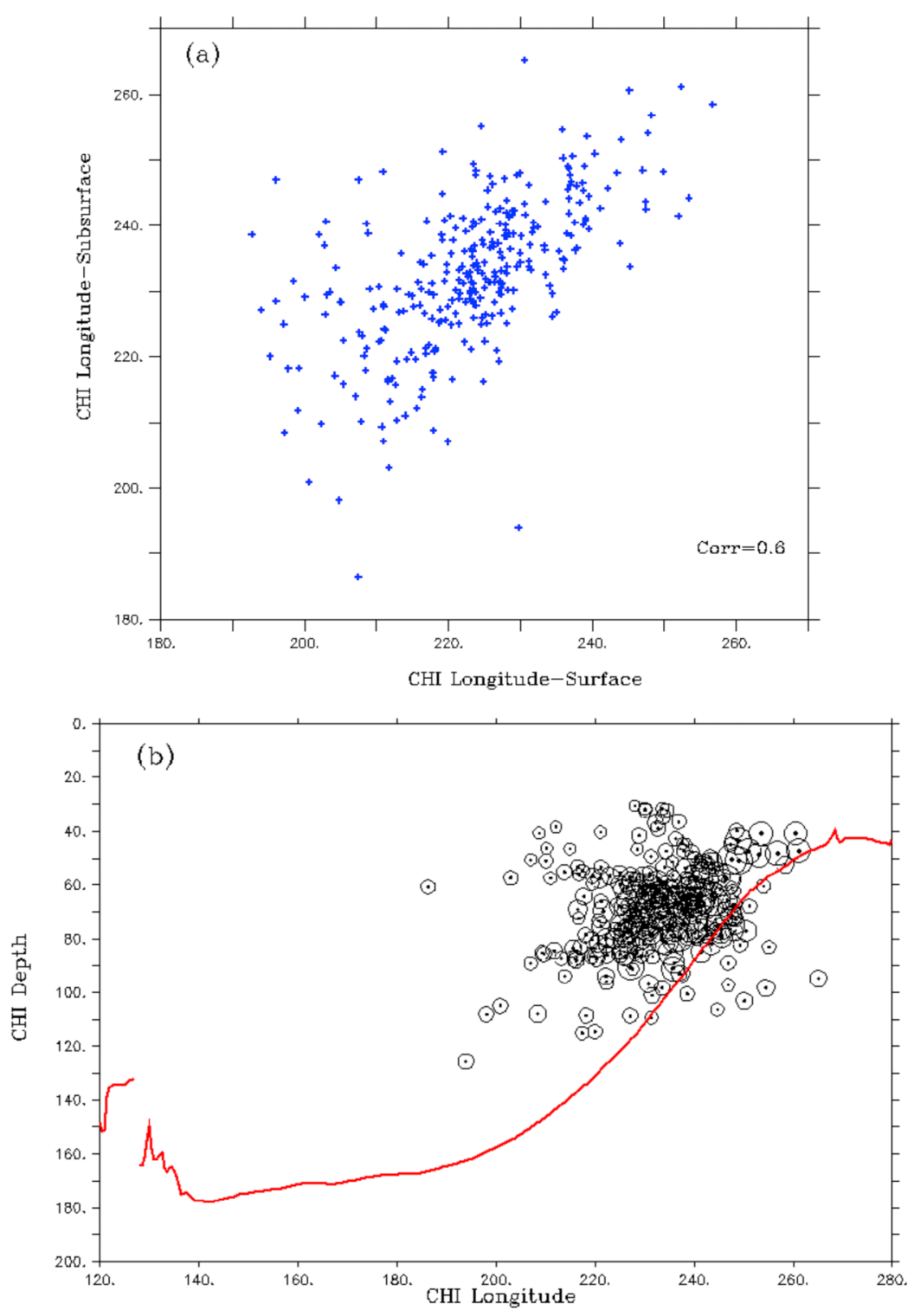

Figure 12. (a) Subsurface $\mathrm{CHI}$ longitude for temperature anomaly greater than $1^{\circ} \mathrm{C}$ plotted as a function of CHI longitude for SST anomaly greater than $0.5^{\circ} \mathrm{C}$. The correlation between the two values is shown inside the plot. (b) $\mathrm{CHI}$ depth for subsurface temperature anomaly greater than $1{ }^{\circ} \mathrm{C}$ plotted as a function of CHI longitude for the same subsurface anomaly and overlaid by the mean position of the $20^{\circ} \mathrm{C}$ isotherm.

compared to warm events. There is a prominent asymmetry in the durations of El Niño and La Niña. The asymmetry could be due to differences in the dynamics of evolution of the two types of events. A second cooling in the eastern Pacific during the end of year 1 of La Niña events of 1980 2008 is also significant. This calls for a closer look into conditions favoring such an evolution of the cold anomaly.

[33] The direction of propagation of El Niño or La Niña anomalies does not show a significant change in the record, although there is a suggestion of propagation in anomalies warmer than $0.5^{\circ} \mathrm{C}$ during El Niño. The direction of propagation of these anomalies does not change much between the composites of El Niños during 1950-1976 and those during
1980-2008. The composite of El Niño from 1980 to 2008 is distinct due to the appearance of small warm anomalies around the dateline in the beginning of the warm event. The direction of propagation of La Niña anomalies does not show a notable change from 1871 to 2008 . The composite of La Niña during 1980-2008 shows cold anomalies reappearing at the end of year 1 and thus prolonging the cold event.

[34] The reanalysis is also used to explore subsurface anomalies during ENSO events. The mean location of $\mathrm{CHI}$ longitude in the subsurface is about $3^{\circ}$ east of the mean $\mathrm{CHI}$ longitude at the surface. The location of subsurface warming follows the mean position of the $20^{\circ} \mathrm{C}$ isotherm depth as it shoals toward the east. As has been previously shown for SST, the distribution of the location of ENSO cannot be 
distinguished from a normal distribution centered in the central Pacific Ocean.

[35] Overall, there is no evidence that there are changes in the strength, frequency, duration, location or direction of propagation of El Niño and La Niña anomalies caused by global warming during the period from 1871 to 2008 . In a recent paper Stevenson et al. [2012] suggest that changes in ENSO characteristics might not occur concurrent with changes in the climate. Instead, the impact of changing climate may cause ENSO to change more than a century after the change in the climate first occurs. In our study we show that a central Pacific warming cannot be distinguished from an eastern Pacific type warming in a record of 138 years of El Niño. As Newman et al. [2011] point out, although anthropogenic forcing might drive changes in ENSO [Yeh et al., 2009] the changes are so small that with short data sets and comparatively small model ensembles [Deser et al., 2011; Coelho and Goddard, 2009] it is hard to separate the anthropogenic from the natural variability. Thus, decadal change in the strength of El Niño could well be part of its natural variability.

[36] Climate change is an ongoing process that is expected to continue in the future, but how El Niño and La Niña variability will react to this change is yet unresolved. Both an increase and decrease in the intensity of El Niño activity under future climate change scenarios has been argued. Of course it is possible that global warming might influence ENSO teleconnections instead of affecting the ENSO variation itself, although there are studies suggesting little change in ENSO teleconnections, at least in the tropics [Coelho and Goddard, 2009]. Other studies suggest that under future global warming scenarios the midlatitude drought areas will increase [Sheffield and Wood 2008] and the tropical cyclone intensity will increase [Knutson et al., 2010]. This could alter these El Niño teleconnections.

\section{References}

An, S.-I., and B. Wang (2000), Interdecadal change of the structure of the ENSO mode and its impact on the ENSO frequency, J. Clim., 13, 2044-2055, doi:10.1175/1520-0442(2000)013<2044:ICOTSO > 2.0 . $\mathrm{CO} ; 2$.

An, S.-I., J.-S. Kug, Y.-G. Ham, and I.-S. Kang (2008), Successive modulation of ENSO to the future greenhouse warming, J. Clim., 21, 3-21, doi:10.1175/2007JCLI1500.1.

Boyer, T. P., et al. (2009), World Ocean Database 2009, NOAA Atlas NESDIS, vol. 66, edited by S. Levitus, 216 pp., U.S. Gov. Print. Off., Washington, D. C.

Carton, J. A., and B. S. Giese (2008), A reanalysis of ocean climate using simple ocean data assimilation (SODA), Mon. Weather Rev., 136, 2999-3017, doi:10.1175/2007MWR1978.1.

Carton, J. A., G. Chepurin, X. Cao, and B. S. Giese (2000a), A Simple Ocean Data Assimilation analysis of the global upper ocean 1950-1995, Part 1: Methodology, J. Phys. Oceanogr., 30, 294-309, doi:10.1175/1520-0485 (2000)030<0294:ASODAA $>2.0 . \mathrm{CO} ; 2$.

Carton, J. A., G. Chepurin, and X. Cao (2000b), A simple ocean data assimilation analysis of the global upper ocean 1950-1995 Part 2: Results, J. Phys. Oceanogr., 30, 311-326, doi:10.1175/1520-0485(2000) $030<0311$ :ASODAA $>2.0 . \mathrm{CO} ; 2$.

Carton, J. A., H. F. Seidel, and B. S. Giese (2012), Detecting historical ocean climate variability, J. Geophys. Res., 117, C02023, doi:10.1029/ 2011JC007401.

Cobb, K. M., C. D. Charles, H. Cheng, and R. L. Edwards (2003), El Niño/ Southern Oscillation and tropical Pacific climate during the last millennium, Nature, 424, 271-276, doi:10.1038/nature01779.

Coelho, C. A. S., and L. Goddard (2009), El Niño-induced tropical droughts in climate change projections, J. Clim., 22, 6456-6476, doi:10.1175/ 2009JCLI3185.1.
Cole, J. E., R. G. Fairbanks, and G. T. Shen (1993), Recent variability in the Southern Oscillation: Isotopic results from a Tarawa Atoll coral, Science, 260, 1790-1793, doi:10.1126/science.260.5115.1790.

Compo, G. P., et al. (2011), The twentieth century reanalysis project, $Q$. J.R. Meteorol. Soc., 137, 1-28, doi:10.1002/qj.776.

D’Arrigo, R., E. R. Cook, R. J. Wilson, R. Allan, and E. Mann (2005), On the variability of ENSO over the past six centuries, Geophys. Res. Lett., 32, L03711, doi:10.1029/2004GL022055.

DelSole, T., and M. K. Tippett (2009), Average predictability time. Part I: Theory, J. Atmos. Sci., 66, 1172-1187, doi:10.1175/2008JAS2868.1.

Deser, C., A. Phillips, V. Bourdette, and H. Tang (2011), Uncertainity in climate change projections: The role of internal variability, Clim. Dyn., 38, 527-546, doi:10.1007/s00382-010-0977-x.

DiNezio, P. N., A. Clement, G. A. Vecchi, B. Soden, A. J. Broccoli, B. L. Ottto-Bliesner, and P. Braconnot (2011), The response of the Wlaker circulation to Last Glacial Maximum forcing: Implications for detection in proxies, Paleoceanography, 26, PA3217, doi:10.1029/2010PA002083.

Enfield, D. B., and L. Cid (1991), Low-frequency changes in El NiñoSouthern Oscillation, J. Clim., 4, 1137-1146, doi:10.1175/15200442(1991)004<1137:LFCIEN>2.0.CO;2.

Fedorov, A. V., and S. G. Philander (2000), Is El Niño changing?, Science, 288, 1997-2002, doi:10.1126/science.288.5473.1997.

Fedorov, A. V., and S. G. Philander (2001), Stability analysis of tropical ocean-atmosphere interactions: Bridging measurements and theory for El Niño, J. Clim., 14, 3086-3101, doi:10.1175/1520-0442(2001) 014<3086:ASAOTO>2.0.CO;2.

Giese, B. S., and S. Ray (2011), ENSO variability in simple ocean data assimilation (SODA), 1871-2008, J. Geophys. Res., 116, C02024, doi:10.1029/2010JC006695.

Jones, P. W. (1999), First- and second-order conservative remapping schemes for grids in spherical coordinates, Mon. Weather Rev., 127, 2204-2210, doi:10.1175/1520-0493(1999)127<2204:FASOCR>2.0.CO;2.

Kaplan, A., M. Cane, Y. Kushnir, A. Clement, M. Blumenthal, and B. Rajagopalan (1998), Analyses of global sea surface temperature 1856-1991, J. Geophys. Res., 103(C9), 18,567-18,589, doi:10.1029/ 97JC01736.

Knutson, T. R., J. L. McBride, J. Chan, K. Emanuel, G. Holland, C. Landsea, I. Held, J. P. Kossin, A. K. Srivastava, and M. Sugi (2010), Tropical cyclones and climate change, Nat. Geosci., 3, 157-163, doi:10.1038/ ngeo 779 .

Lee, T., and M. J. McPhaden (2010), Increasing intensity of El Niño in the central-equatorial Pacific, Geophys. Res. Lett., 37, L14603, doi:10.1029/ 2010GL044007

Li, J., S.-P. Xie, E. R. Cook, G. Huang, R. D’Arrigo, F. Liu, J. Ma, and X.-T. Zheng (2011), Interdecadal modulation of El Niño amplitude during the past millennium, Nature Clim. Change, 1, 114-118, doi:10.1038/nclimate1086.

McPhaden, M. J., and X. Zhang (2009), Asymmetry in zonal phase propagation of ENSO sea surface temperature anomalies, Geophys. Res. Lett., 36, L13703, doi:10.1029/2009GL038774.

Merryfield, W. J. (2006), Changes to ENSO under CO2 doubling in a multimodel ensemble, J. Clim., 19(16), 4009-4027, doi:10.1175/JCLI3834.1.

Newman, M., S.-I. Shin, and M. A. Alexander (2011), Natural variation in ENSO flavors, Geophys. Res. Lett., 38, L14705, doi:10.1029/ 2011 GL047658.

Okumura, Y. M., and C. Deser (2010), Asymmetry in the duration of El Niño and La Niña, J. Clim., 23, 5826-5843, doi:10.1175/ 2010JCLI3592.1.

Okumura, Y. M., M. Ohba, C. Deser, and H. Ueda (2011), A proposed mechanism for the asymmetric duration of El Niño and La Niña, J. Clim., 24, 3822-3829, doi:10.1175/2011JCLI3999.1.

Philip, S., and G. J. van Oldenborgh (2006), Shifts in ENSO coupling processes under global warming, Geophys. Res. Lett., 33, L11704, doi:10.1029/2006GL026196.

Rayner, N. A., D. E. Parker, E. B. Horton, C. K. Folland, L. V. Alexander, D. P. Rowell, E. C. Kent, and A. Kaplan (2003), Global analyses of sea surface temperature, sea ice, and night marine air temperature since the late nineteenth century, J. Geophys. Res., 108(D14), 4407, doi:10.1029/ 2002JD002670.

Reynolds, R. W., N. A. Rayner, T. M. Smith, D. C. Stokes, and W. Wang (2002), An improved in situ and satellite SST analysis for climate, J. Clim., 15, 1609-1625, doi:10.1175/1520-0442(2002)015<1609:AIISAS>2.0.CO;2.

Schubert, S. D., M. J. Suarez, P. J. Pegion, R. D. Koster, and J. T. Bacmeister (2004), On the cause of the 1930s Dust Bowl, Science, 303, 1855-1859, doi:10.1126/science. 1095048 .

Sheffield, J., and E. F. Wood (2008), Projected changes in drought occurrence under future global warming from multi-model, multi-scenario, IPCC AR4 simulations, Clim. Dyn., 31, 79-105, doi:10.1007/s00382007-0340-z. 
Smith, R. D., J. K. Dukowicz, and R. C. Malone (1992), Parallel ocean general circulation modeling, Physica D, 60, 38-61, doi:10.1016/01672789(92)90225-C

Smith, T. M., and R. W. Reynolds (2005), A global merged land air and sea surface temperature reconstruction based on historical observations (1880-1997), J. Clim., 18, 2021-2036, doi:10.1175/JCLI3362.1.

Smith, T. M., R. W. Reynolds, T. C. Peterson, and J. Lawrimore (2008), Improvements to NOAA's historical merged land-ocean surface temperature analysis (1880-2006), J. Clim., 21, 2283-2296, doi:10.1175/ 2007JCLI2100.1.

Stevenson, S., B. Fox-Kemper, M. Jochum, R. Neale, C. Deser, and G. Meehl (2012), Will there be significant change to El Niño in the 21st century?, J. Clim., 25, 2129-2145, doi:10.1175/JCLI-D-11-00252.1.

Timmermann, A., J. Oberhuber, A. Bacher, M. Esch, M. Latif, and E. Roeckner (1999), Increased El Niño frequency in a climate model forced by future greenhouse warming, Nature, 398, 694-697, doi:10.1038/19505.

Trenberth, K. E., and T. J. Hoar (1996), The 1990-1995 El Niño-Southern Oscillation event: Longest on record, Geophys. Res. Lett., 23(1), 57-60, doi:10.1029/95GL03602.

Trenberth, K. E., and T. J. Hoar (1997), El Niño and climate change, Geophys. Res. Lett., 24(23), 3057-3060, doi:10.1029/97GL03092.

Trenberth, K. E., D. P. Stepniak, and J. M. Caron (2002), Interannual variations in the atmospheric heat budget, J. Geophys. Res., 107(D8), 4066, doi:10.1029/2000JD000297.

Tudhope, A. W., C. P. Chilcott, M. T. McCulloch, E. R. Cook, J. Chappell, R. M. Ellam, D. W. Lea, J. M. Lough, and G. B. Shimmield (2001), Variability in the El Niño-Southern Oscillation through a glacial-interglacial cycle, Science, 291, 1511-1517, doi:10.1126/science.1057969. van Oldenborgh, G. J., S. Y. Phiilip, and M. Collins (2005), El Niño in a changing climate: A multi-model study, Ocean Sci., 1, 81-95, doi:10.5194/os-181-2005.

Vecchi, G. A., and B. J. Soden (2007), Global warming and weakening of the tropical circulation, J. Clim., 20, 4316-4340, doi:10.1175/ JCLI4258.1.

Vecchi, G. A., and A. T. Wittenberg (2010), El Niño and our future climate: Where do we stand?, WIREs Clim. Change, 1, 260-270, doi:10.1002/ wcc.33.

Wang, B. (1995), Interdecadal changes in El Niño onset in the last four decades, J. Clim., 8, 267-285, doi:10.1175/1520-0442(1995)008<0267: ICIENO $>2.0 . \mathrm{CO} ; 2$

Wang, B., and S.-I. An (2002), A mechanism for decadal changes of ENSO behavior: Roles of background wind changes, Clim. Dyn., 18, 475-486, doi:10.1007/s00382-001-0189-5.

Yang, H., and Q. Zhang (2008), Anatomizing the Ocean's role in ENSO changes under global warming, J. Clim., 21, 6539-6555, doi:10.1175/ 2008JCLI2324.1.

Ye, Z., and W. W. Hseih (2008), Changes in ENSO and associated overturning circulations from enhanced greenhouse gases by the end of the twentieth century, J. Clim., 21, 5745-5763, doi:10.1175/2008JCLI1580.1.

Yeh, S.-W., J.-S. Kug, B. Dewitte, M.-H. Kwon, B. P. Kirtman, and F. F. Jin (2009), El Niño in a changing climate, Nature, 461, 511-514, doi:10.1038/nature 08316

Zhang, Q., Y. Guan, and H. Yang (2008), ENSO amplitude change in observation and coupled models, Adv. Atmos. Sci., 25, 361-366, doi:10.1007/ s00376-008-0361-5. 